\title{
PERSONAL HYGIENE AND PUBLIC HEALTH CARE IN THE POLISH COUNTRYSIDE AFTER 1945 - PROPAGANDA AGAINST REALITY*
}

Zarys treści: W nowym powojennym modelu systemu państwowej służby zdrowia aż do lat 70 . XX w. jedyną grupą społeczną pozostająca na jego marginesach byli rolnicy indywidualni. Pozostawienie ludności wiejskiej poza systemem bezpłatnej opieki medycznej i tym samym zmuszenie dorosłych jej reprezentantów do ponoszenia wysokich kosztów leczenia powszechnych wówczas schorzeń zdrowotnych (np. gruźlicy) stanowić miało w latach 50. jedna z form stalinowskiej polityki opresyjnej. W rzeczywistości jednak sytuacja taka wymuszona była przede wszystkim niewydolnością ekonomiczna kadrową i organizacyjną odbudowywanego państwa.

Instalowane lub docierające na wieś lat 50. instytucje opieki medycznej bezpłatna pomoc oferowały tylko małym i dorastajacym dzieciom oraz kobietom w ciąży. Wygenerowana powojenna przebudową struktury społecznej i własnościowej dynamicznie narastająca mobilność społeczna polskiej wsi stawała się coraz istotniejszym czynnikiem wspierającym modernizacyjne działania władz centralnych. Celem tekstu jest zarysowanie skali wiejskich problemów zdrowotnych w okresie tużpowojennym. Traktując okres ten jako swego rodzaju punkt wyjścia, w tekście podejmę również próbę scharakteryzowania kierunków i tempa przemian dokonujących się w życiu codziennym polskiej wsi w obszarze zdrowia do początku lat 70 . ubiegłego stulecia.

The content outline: In a new post-war model of the state healthcare system the only group that stayed on its margin until the 1970s were individual farmers. Leaving the peasants outside the system of free medical care and thus forcing adult members of this class to pay high costs of treatment of common at that time medical maladies (such as, for example, tuberculosis) was in the 1950s one of the forms of oppressive Stalinist policy. In fact, however, such

* The research was financed from the resources of the National Science Center granted as part of the internship after obtaining the doctoral degree on the basis of Decision no. DEC-2012/04/S/HS3/00316. 
a situation was forced mainly by economic, personnel, and organisational malfunction of the reconstructed state.

Institutions of medical care that reached the countryside or were established there in the 1950s, provided free medical coverage only for children and pregnant women. A rapidly growing social mobility of the Polish countryside generated by the post-war revamping of social and ownership structure was becoming an increasingly important factor supporting modernisation actions of the central authorities. The purpose of the present study is to outline the scale of medical and health problems in the Polish countryside immediately after the war. Treating this period as a peculiar starting point, I also make an attempt to characterise directions and pace of changes occurring in the everyday health life of the Polish country to the 1970s.

Słowa kluczowe: historia społeczna, wieś polska, higiena, polityka zdrowotna, modernizacja

Keywords: social history, Polish countryside, hygiene, health care policy, modernisation

"A visit to the health centre" is the title of newsreel from 1950, presenting the health centre in the nationalized village of Krowiarki. The film shows well-equipped offices, permanent medical staff and numerous of satisfied patients examined by a dentist, doctor and nurse, working with enthusiasm. The lector commenting the chronicle assures the viewers that "the time of quack doctors and 'grandmothers' in the countryside has ended, and mothers and infants in delivery rooms are surrounded by loving and professional care". ${ }^{1}$ The commentator of another chronicle of the same year ("The ambulance going to the countryside") assures that "one of the most important concerns of the people's state is to provide medical care for the working population". ${ }^{2}$

In addition to the unambiguously positive image, a common feature of the two films is that they describe nationalized (PGR) and socialized (cooperatives) villages, consistent with the ideological assumptions of socialism. Although the commentary mentions the Polish countryside, the traditional one,$^{3}$ created by peasants working in their own field does not appear.

1 "W wiejskim ośrodku zdrowia" (Polska Kronika Filmowa 50/25), http://www. kronikarp.pl/szukaj,19772,tag-689431,strona-2 (accessed: 31 Dec. 2014).

2 "Ambulans jedzie na wieś, 1952 (Polska Kronika Filmowa 50/25) http://www. kronikarp.pl/szukaj,10896,strona-2 (accessed: 31 Dec. 12014).

3 The agricultural policy, implemented since 1948, was based on the idea of tripartite division of sectors in agriculture, created by state farms (state farms, modelled 
In fact, in the first decade after the war the propaganda very rarely presented the so-called individual village in bright colours. Usually, the countryside was depicted as a bastion of backwardness, superstitions, and "practices of quack doctors rapidly evolving among the population" as well as low awareness of hygiene, which, among other things, was visible in the living conditions and health status of rural residents.

In practice, however, at the beginning of the 1950s, the countryside (rural community), although arbitrarily (ideologically, and in many areas also with the use of violence) divided into three sectors, was homogeneous in terms of health awareness.

Variations observed in the sources were more dependent on individual experience, wealth or level of education of particular persons rather than on their membership in a particular sector of the economy. However, according to the then state social policy, this membership decided on the rural population access to healthcare.

The health system, rebuilt after the war, was to be based on the Soviet model. According to it, the health care was to be state, common, uniform and complex. ${ }^{4}$ According to this model, it would cover the whole of society, guaranteeing all citizens accessible and free health services. ${ }^{5}$ In reality, however, the construction of the health care system proceeded in stages and formally (not necessarily in practice) the free and universal access to health care happened only in the 1970s, ${ }^{6}$ when the free health care included the peasants, who, at that time constituted nearly 50 per cent of the then population of the Polish People's Republic (PRL) (approx. 16 million people). It is worth noting that twenty years ago the percentage was even higher, and just after the war, the villagers constituted almost 70 per cent of the total population. The available materials of the Ministry of Health could provide a conclusion that the incomplete free health care coverage of rural residents was associated primarily with the failure of the system and the lack of sufficient funding. The propaganda and the official discourse (especially of the Stalinist period) focused mainly on the ideological factors. In 1953 in

on the Soviet state farms), socialized farms (cooperatives, modelled on the Soviet collective farms), and private (i.e. individual, usually 5-10 ha, which together with the progressive policies of collectivization were subject to liquidation).

${ }^{4}$ B. Fogt, "Poznański Ośrodek Reumatologiczny w kontekście zmian zachodzących w ochronie zdrowia w latach 1952-2005", PhD dissteriations written uder Prof. Dr hab. Michał Musielak, source: Wielkopolska Biblioteka Cyfrowa, http://www.wbc. poznan.pl/Content/249324/index.pdf (accessed: 19 Dec. 2014).

${ }^{5}$ Ibid., p. 21.

${ }^{6}$ Organizacja ochrony zdrowia, ed. by J. Indulski, Warszawa, 1984, p. 315. 
Zdrowie Publiczne, it was written that "in the struggle for the socialist reconstruction of the village, there should be an active participation of the healthcare, primarily providing care for the socialized country [...] The creation of adequate sanitation conditions in the farm team is, in the current era of the struggle for the socialization of the village, significant not only with regards to health, but also with regards to politics". ${ }^{7}$

Exclusion of individual farmers from the free or discount health benefits would therefore constitute one of the forms of oppressive practices that were to lead the farmers to collectivization (joining a production cooperative or going to work in nationalized agriculture, PGR). ${ }^{8}$

As shown by the materials the state strategy, regarded in this way, sometimes brought results. There were cases that peasants, previously reluctant, after a discovery of a serious illness (them or their families) (e.g. the tuberculosis, which was common at that time), unable to undergo treatment at their own expense, joined the local production cooperative. ${ }^{9}$ It is difficult to estimate the scale of this phenomenon. In the 1950s the land was still regarded as the highest value in the peasant worldview and giving it away, even at the cost of the health or life of a family member, was not an option. The rural attitude towards the state health care was also quite ambivalent.

\section{Hygiene, living conditions and health status of the peasants in the 1940s and 1950s}

In this situation, the results of field studies carried out since the beginning of the 1950s by the students of the Medical University of

${ }^{7}$ M. Jarosz, S. Kosiński, "Geneza i zmiany strukturalne wiejskiej służby zdrowia", in: Stare i nowe struktury społeczne w Polsce, vol. 2: Wieś, ed. by J. Styka, Lublin, 1995, p. 169.

${ }^{8}$ Rural women had the right to free health care outpatient services during pregnancy and childbirth (K clinics, maternity wards); also all infants up to 1 year of age were covered by free medical care (including outpatient facilities D), and the children of farmers up to 14 years of age could benefit from free medical care, dental, nursing and rehabilitation services. Apart from medicines for infants, the farmers, however, were not entitled to any discounts on pharmaceuticals, the full price was also applied in case of a treatment of patient over 14 years of age - except it was the treatment of tuberculosis (since 1959) and infectious diseases which were subject to forced hospitalization. Free were also the services of specialist clinics (anti-alcoholic, cancer, mental health, and vaccinations); see Organizacja ochrony zdrowia, ed. by J. Indulski, Warszawa, 1984, p. 316.

${ }^{9}$ Interview with F.R., an inhabitant of the M. village, West Pomeranian Voivodeship. 
Lublin do not provide very astonishing results. The research shows how the then villages were neglected in terms of health and hygiene ${ }^{10}$.

For a large part of the adult rural population studied, these camps were the first ever contact with the doctor (previously they used at most the tips of a nearby pharmacist or a quack doctor). ${ }^{11}$ Mainly, the level of personal hygiene was very poor and so were the living conditions and health status of the rural residents, only indirectly dependent on the health awareness. Body wash was not an everyday habit for most of them. Bowls used for ablution indeed occurred in the studied farms, but quite often they served also as utensils to wash dirty pots and kitchen plates. ${ }^{12}$

A large percentage of women (in some villages even half of them) did not use the lower underwear, while every fourth woman was to bathe once a week in an iron tub, and 67 per cent did not bathe at all or only during the holidays. ${ }^{13}$ Nearly 95 per cent of the families used the same towel, and there was a toothbrush only in 30-40 per cent of the houses. Its occurrence, however, was no indication of oral hygiene - it happened that one brush was, from time to time, used by all members of the family). Dental health of rural residents in the 1950s (and also in the 1960s) was very bad, and it was also associated with difficult access to dental treatment services. The big problem was the caries reaching over 50 per cent in case of children 3-7 years of age and the lack of all teeth often occurring in women 30-40 years old. ${ }^{14}$ According to the focus research conducted in 1959 on 350 rural women, most of them had a very bad diet during pregnancy, further reinforcing their dental problems.

${ }_{10}$ Problems concerning hygenization are also discussed by professor Magdalena Florek-Łuszczyk in her book: Higienizacja polskiej wsi jako ruch socjomedyczny, Lublin, 2015, p. 44-54.

${ }^{11}$ From among 3,5 thousand interviewed people 800 declared the first contact with doctor, see: W. Szewczykowski, Z. Bryc, W. zbroja, A. Łuj, D. Pomyklaska, "Ocena stanu zdrowia ludności wiejskiej powiatu parczewskiego w świetle badań obozu naukowo-społecznego w Sosnowicy", in: Stan zdrowotny i higiena wsi lubelskiej. Materiały z obozów naukowo-społecznych 1954-1960, ed. by S. Grzycki, A. Tuszkiewicz, W. Szewczykowski, B. Wawrzyszuk, Lublin, 1964, p. 16.

12 J. Danielski, B. Wawrzyszuk, A. Stankiewicz, M. Kowalczyk, "Badania ogniskowe stanu sanitarno-epidemiologicznego wybranych wsi gromady Świeciechów”, in: Stan zdrowotny i higiena wsi lubelskiej, p. 27.

${ }^{13}$ R. Sikorski, "Dalsze badania nad stanem zdrowia kobiet wiejskich", in: Stan zdrowotny i higiena wsi lubelskiej, p. 173.

${ }^{14}$ In 1962, it was estimated that of 6 per cent of women in this age had no teeth at all; see: B. Wawrzyszuk, "Stan sanitarno-higieniczny wsi", in: Oświata sanitarna na wsi. Higienizacja wsi, Warszawa, 1962, p. 20. 
The flats very often were not aired for weeks or months - windows were usually small and remained sealed to protect against heat loss in the winter and against the flies in the summer. ${ }^{15}$ In many rural houses, which survived the war, a clay floor could be found, considered to be non-staining by many housewives. ${ }^{16}$ Almost everywhere (except perhaps of the best preserved buildings in the west and north territories, incorporated to Poland after the war) there was no water supply or sewage system. Wells, destroyed or contaminated, were one of the major ills of Polish village sanitation long after the war, and the problems with access to water significantly affected the hygienic habits.

It is also worth mentioning that in the most war-torn areas at least until the early 1950s many rural inhabitants lived in the vast poverty and conditions incompatible with the then prevailing standards of hygiene. ${ }^{17}$ In the villages, which had were the front line during the war, most of the residential buildings were destroyed. For this reason, many people in the first few years after the war used a dugout or a different provisory construction as a home.

However, also the state of preserved housing, especially in eastern Poland, left much to be desired - the majority of houses were made of wood, covered with a thatched roof and located in the immediate vicinity of livestock buildings (i.e. coupled constructions). The difficult housing conditions in the context of hygiene were mentioned at the end of the 1940s by one of the rural doctors:

The conditions under which births took place were different, depending on the financial status and the willingness to use hygiene. Unfortunately, I didn't see many neat rooms in those days [...] in a small dark chamber with a tiny window size of a cap, with the threshing floor of clay, on a cot covered with straw there was a woman in labour. I had to provide on-site assistance. Meanwhile, back to the cot, there was a tethered horse. Yet never have I taken birth in such close proximity to a horse. I was within the dangerous range of his hooves and at any moment I was exposed to an unexpected kick. ${ }^{18}$

${ }^{15}$ Cf. Pamiętniki lekarzy, ed. by J. Borkowski, Łódź, 2011 (1 ${ }^{\text {st }}$ ed.: 1938); M. Kacprzak, Konkursy “Zdrowie w chacie wiejskiej”. Sprawozdanie i uwagi krytyczne, Warszawa, 1930.

${ }_{16}$ M. Kacprzak, op. cit., p. 42.

${ }^{17}$ A dramatic situation in the Kielce province was described by, for example, Grzegorz Miernik, see: G. Miernik, "O niektórych patologiach życia codziennego mieszkańców obszarów przyczółkowych w drugiej poł. lat 40. XX w. (na przykładzie woj. kieleckiego)", in: Bieda w Polsce, ed. by G. Miernik, Kielce, 2012, p. 195-216.

${ }_{18}$ Pamiętniki lekarzy, ed. by K. Bidakowski, T. Wójcik, Warszawa, 1968, p. 818. 
The surroundings of the rural farms also looked very bad in terms of sanitation and hygiene. Many farms still did not have a lavatory. In the households, where there was a lavatory, it was usually situated in the wrong place or was poorly secured. This contributed to the presence of swarms of flies and the land pollution. This also applied to rural dunghills which were usually located too close to residential buildings and wells, and constituted a real threat of spreading of infectious diseases (especially paratyphoid fever), or food poisoning. In the materials describing the rural sanitation conditions it has also been highlighted that there was a lack of refuse dumps resulting in widespread dirt and disorder of the area, surrounding the farms.

Of course, the living conditions described have an influence on the overall health of the residents. In the studied area of eastern Poland, more than half of the residents questioned declared passage of infectious disease (usually it was the measles - 26 per cent, 17 per cent - typhoid fever or a respiratory disease - 14 per cent). In case of women, particularly frequent were the genital diseases and various types of inflammation, underestimated by them. Skin disorders (mostly untreated), including allergic reactions, also occurred frequently. Due to the living conditions common were rheumatic diseases and parasitic zoonoses (including tuberculosis) as well as mould infections. ${ }^{19}$ Yet, in 1959, during a meeting in the Ministry of Health, one of the doctors alarmed: "No one deals with the mould issue. E.g. there is mould infestation in the village of Kazimierz, whereas the presence of the patients with Racławice forces others to open the windows, as you can smell mildew from them". ${ }^{20}$

After the war, however, the state of health of Polish children was particularly worrisome. First of all, the infant mortality rate was extremely high for the then European conditions - in 1955 in many provinces the rate amounted to more than 8 per cent, while in western Europe it ranged from 1.8 per cent to 2.3 per cent, and for example in the neighbouring Czechoslovakia it was 3.5 per cent. ${ }^{21}$

${ }^{19}$ Cf. Ksiega Pamiatkowa Zjazdu Medycyny Wiejskiej w Lublinie. Z okazji X-lecia Instytutu Medycyny Pracy i Higieny Wsi im. Witolda Chodźki 1951-1961, ed. by J. Parnas, Lublin, 1964, pp. 148-149 ff.

${ }^{20}$ Central Archives of Modern Records in Warsaw (hereafter: AAN), Ministry of Health (hereafter: MZ), Cabinet of Minister Presidium Department (hereafter: GMWP), Posiedzenie Kolegium Ministerstwa 10-14. Protokoły, załączniki 1959, ref. no. 1/41, Protokół z narady aktywu służby zdrowia odbytej dnia 26 marca $1959 \mathrm{r}$. w sali Prezydium WRN w Opolu, leaf 406.

${ }^{21}$ AAN, MZ, GMWP, Posiedzenie Kolegium Ministerstwa 32-37. Protokoły, załączniki 1958, ref. no. 1/38, Ocena działalności służby zdrowia woj. wrocławskiego, leaf 27. 
Of course, such a high proportion of infant deaths resulted from a low sanitary culture, but the reasons for this were sought also in other factors ${ }^{22}$. This problem, noticed in the cities, was worse in Polish provinces. In the countryside, the health conditions of children over 2 years old also looked very bad. According to the study conducted in several villages of the Łódź region (central Poland) up to 83 per cent of children under 3 years of age suffered from rickets, and one in four children had the severe form of rickets. Every third child aged 1-7 years had worms (Helictotrichon, human worm, Taeniasis). The most common diseases in case of rural children were: measles, whooping cough, pneumonia, diphtheria, as well as scarlet fever and mumps. Complications of whooping cough, pneumonia, injuries and accidents, as well as diphtheria were the most often causes of death in the Zelechlinek village. It was diphtheria that gathered a special toll in Poland in the period of 1950-1955.

As Dariusz Jarosz pointed out in his study, in 1958, one in eleven infants born alive in the rural areas was to die in their first year of life; in one in twenty houses in the countryside there was a serious risk to the child of tuberculous infection (from the oldest members of the family); every twelfth rural child was threatened with a heart defect from rheumatic disease (rheumatoid), and one in ten young persons in the countryside was to have severe physical deficiencies. ${ }^{23}$ In the villages of the Lublin province more than half of the surveyed children in the 1950s showed weight and height deficiencies, associated most often with malnutrition or deficiencies of protein and vitamins in the diet. ${ }^{24}$

The high infant mortality rate (as well as female perinatal complications) meant that the issue of the pregnant women protection was one of the priorities. The desire to minimize the number of births received by unqualified personnel (in the countryside the so-called grandmothers) was implemented through the creation of rural birth chambers. Their operation in the villages reflected problems similar to those observed in the case of health centres. The lack of staff was not always the only reason for difficulties. Very often the women themselves (at least until the end of the 1950s and often in the 1960s) underestimated checkups during pregnancy, having their first visit to the emergency room

${ }^{22}$ These included insufficient number of vaccinations against infectious diseases, inadequate medical care, too fast check-outs from maternity hospitals, nosocomial infections, etc.

${ }^{23}$ D. Jarosz, Obraz chłopa w krajowej publicystyce czasopiśmienniczej 1944-1959, Warszawa, 1994, p. 165.

${ }^{24}$ J. Danielski, B. Wawrzyszuk, A. Stankiewicz, M. Kowalczyk, op. cit., p. 24. 
or health centre with a high pregnancy. ${ }^{25}$ The problem was also significant distances. The inability to quickly reach the nearest health centre or medical point often ended tragically. High mortality in the countryside of infants (and the mortality of children up to 2 years of age), was associated, also by the employees of the Ministry of Health, mainly with the problems of transportation (along with poor nutrition and living conditions). ${ }^{26}$ Interestingly, also in the socialized and nationalized villages, equipped with the factory vehicles, which could be used in lifethreatening situations, this problem occurred with a similar intensity: "The managers of PGR (state farms) and production cooperatives are reluctant to provide means of transport to get the child to the doctor. The mother does not have the strength to carry the child for a few, and even more kilometres, and the surgeon on-call also cannot come, because there is no means of transport". ${ }^{27}$ The reluctance of management, moreover, matched the repeatedly signalled attitude of the local authorities towards the health and sanitary education.

Of course, at this point the question arises whether the aforesaid background of rural health and hygiene can be applied to all areas of Poland. Statistics, carried out after 1945, due to communication and staff problems, at least until the mid-1950s included the countryside in a small part. It is due to this reason that the data collected is not representative for all regions of the country. This includes statistics of rural deaths and their causes. Some help is provided in the reports of the Ministry of Health on the state of health and sanitary conditions of individual provinces.

The reports generally confirm the situation described above, although as the analysed memories and more detailed research indicate - sometimes large variations occurred in the context of a village or district. One of the reasons was the distance of a particular settlement from an urban or/and industrial centre (where usually a hospital, a clinic or a health centre were situated). The availability of medical services could also be determined by the location along the busiest routes (e.g. the touristic villages). ${ }^{28}$ The state of affluence and education of the inhabitants

${ }_{25}$ AAN, MZ, GMWP, Posiedzenie Kolegium Ministerstwa 28-33. Protokoły, załączniki 1956, ref. no. 1/27, Stan opieki położniczej i ginekologicznej w kraju i wytyczne na przyszłość, leaf 227.

${ }^{26}$ AAN, MZ, GMWP, Posiedzenie Kolegium Ministerstwa 39-43. Protokoły, załączniki 1955, ref. no. 1/23. Protokół z posiedzenia KMZ w dn. 25 listopada 1955 w Szczecinie, leaf 58.

27 Ibid.

${ }^{28}$ Z. Kaczmarski, I. Birbach, B. Wawrzyszuk, R. Umińska, "Badania stanu higieny wsi Gołąb", in: Stan zdrowotny i higiena wsi lubelskiej, p. 64. 
of the settlement was also of great significance. As shown in the memoirs even in the first years after the war, there were clear differences in relation to hygiene, observed within a single rural community.

This can be seen even in the statement of one of the rural inhabitants:

In my [...] village you can see the ash, soot thrown on the road, as recycle, urine drained onto the road, almost no one subscribes newspapers, dirt in the homes, nobody has any idea about bacteria, the well (if you can call it a well) one every few houses. The floors in homes are rarely washed, the older people can blow their noses to the floor, spit, etc., The buckets are then put on the floor, water brought in them, from the common well, and the bottom of the bucket is then washed, and someone else eats the leftovers. It is not surprising that when there is a disease, it spreads throughout the village. ${ }^{29}$

\section{Mentality and rural attitude to health}

The conditions of life outlined in this way were, on the one hand, linked to the great poverty of the Polish countryside, and, on the other hand, they were a result of the worldview, characteristic for the then countryside. Although the most common modern concept of hygiene was unknown there, it does not mean that the villagers did not develop their own equivalent, which, in fact, was a system of practice, playing a role of a peculiar preventive health care. This function, described by ethnologists and anthropologists, was fulfilled by the magical-religious system of protective measures (apotropaic), and often standing in conflict with the elementary rules of hygiene. In the post-war discourse these measures were called superstitions, witchcraft, evidence of a rural backwardness. This set of protection practices, related to a set of regional cultural baggage is sometimes referred to in medical sociology as "nonmedical treatment". ${ }^{30}$ It was one of the major difficulties in the work of the representatives of local outpatient institutions.

Lacking confidence in medical therapy, the patients usually went to the dental practitioners in the toughest situations or particularly onerous, and they often consulted the diagnosis and treatment methods used with the local quack doctor or a healer. ${ }^{31}$

${ }_{29}$ Wieś polska 1939-1948. Materiaty konkursowe, vol. 2, prep. by K. Kersten, T. Szarota, Warszawa, 1968, p. 80.

${ }^{30}$ For more on the subject, see: W. Piątkowski, Lecznictwo niemedyczne $w$ Polsce. Tradycja i wspótczesność, Lublin, 2008, pp. 9-34.

${ }^{31}$ See, for example, Skalna ziemia, dir. by Włodzimierz Borowik, 1956. 
Of course, it did not always look the same, but the attitude of the rural population towards the doctors was at the time marked by great mistrust. Expensive (not refunded for individual farmers) drugs, often inaccessible and ineffective due to late reporting to a specialist or their too short use by the patient militated in favour of medical treatments.

In the 1950s the treatment rates (including hospitals), unregulated and non-uniform for the whole country, often only deepened the distrustful attitude towards the health care facilities emerging in the villages (health centres, $\mathrm{K}$ clinics, maternity wards, D clinics, medical points, nursing points, etc.).

It was also sustained by a high staff turnover in these institutions, who were quickly discouraged to continue to work in conjunction with low wages, poor equipment in the centres, poor housing conditions (usually there was no housing) or a lack of means of transport necessary for the implementation of mandatory home visits in the subordinate region, etc.

Even in 1958 it was emphasized that the majority of doctors taking up employment in the rural areas are "young and of small experience". Age as well as the related authority and experience were important in rural areas. As shown by statistics, the centres and clinics operated by an elderly staff reported more than twice as many rural patients than the centres run by a young graduate of the Academy of Medicine. ${ }^{32}$ This also applied to medical assistants whose qualifications in the 1950s were often debatable, and methods of treatment were often similar to those used by local quack doctors. ${ }^{33}$ There is no denying that in many parts of quack treatments, referring to the belief system was more convincing to the patients. The provincial doctors were also aware of that. One of them even tried a kind of compromise:

Dr. Trześniewski had a totally different approach to people. He settled in the farthest village between Lipniaki and Szczuchnie and started to pretend to be a quack doctor. He did not admit to have a medical diploma. He used a rational therapy, but with a certain quack modification. The prescribed potion necessarily had to mix in half with holy water and drink three times a day with a wooden spoon. Powders needed to be dissolved in spring water, taken from the forest spa at the full moon. To put a man on

${ }^{32}$ National Archives in Cracow (hereafter: ANK), Voivodship Sanitary Epidemiological Station (hereafter: WSSE), ref. no. 168, leaf 5.

${ }^{33}$ AAN, MZ, GMWP, ref. no. 1/36, Posiedzenia Kolegium Ministerstwa nr 21-24, protokoły, załączniki, 1958 r., Protokół narady aktywu służby Zdrowia w Kielcach w dniu 26 VI 1958 r., leaf 272. 
his feet, a chicken had to be slaughtered at midnight, cook the whole day in a clay pot and after sunset it should be given to the patient. The fame of a good doctor quickly spread, and after a few months, he was treating half of the region. But the militia did not like this, they started to put blame on him, and then the healer revealed who he was and he was gone. ${ }^{34}$

The difficulties of doctor's work resulting from the rural mentality were also the same in case of other healthcare professionals. They were experienced by, among other things, nurses and members of the teams in charge of mandatory vaccinations in the countryside. ${ }^{35}$ This problem, current in the mid-1950s, was, among others, an evidence of a poor efficiency of the contemporary health education.

\section{Hygiene movement and health education before and after 1945}

The central authorities were aware of the appalling sanitary conditions in the rural areas long before 1939. Regional variations in relation to health and safety issues were also associated with the heritage of Polish partition (each state taking part in the partition had another "health policy" in relation to rural areas).

In interwar Poland, united after 1918, this problem was also important and visible. However, the free health care system, sanctioned by the Act of 28 March 1933 on social security, ${ }^{36}$ excluded the farmers and their families. As a consequence, only the wealthiest could afford medical assistance. ${ }^{37}$

The issue of changing the health situation of the village in prewar Poland was raised by many social activists and politicians. One of them was the Prime Minister Felicjan Sławoj-Składkowski, who, in 1928, striving to implement actions to improve awareness of hygiene

${ }^{34}$ Młode pokolenie wsi Polski Ludowej, vol. 7: Nowe zawody, ed. by J. Chałasiński, Warszawa, 1969, p. 144.

${ }^{35}$ For example AAN, MZ GMWP, ref. no. 1/21, Posiedzenie Kol. Min. 21-30. Protokoły, załączniki, 1955, leaves 14-15.

36 The Act of 28 March 1933 on Social Security, Official Journal of Laws (hereafter: Dz.U.) 1933, no. 51, item 396, see also B. Fogt, op. cit., p. 23.

${ }^{37}$ A former rural community worker Ignacy Solarz wrote bluntly on this subject: "Chłop za przyjazd lekarza i poradę do domu płaci cielęciem, za przyjazd do ciężkiego porodu krową lub koniem, za dłuższe leczenie szpitalne płaci ziemią. Nie starczy gospodarstwa na ratowanie całej rodziny", I. Solarz, Historia powstania Spótdzielni Zdrowia w Markowej, Warszawa, 1937, p. 18, after: Pamiętniki lekarzy, 2011, p. 67. 
of Polish peasantry, contributed to issuing a regulation requiring the construction of the built-up lavatories on each occupied lot. The lavatories are still commonly referred to as "sławojki". ${ }^{38}$ Top-down efforts to improve the hygienic conditions of the Polish countryside were limited. The representatives of the Polish Society of Hygiene played an important role in this matter (especially Martin Kacprzak, the initiator of transposing the American concept of sanitary districts and health centres to Poland) ${ }^{39}$ Although the idea was met with great enthusiasm of local communities, due to the crisis of the 1930s and the state's financial problems effective implementation of the plan of broad and effective improvement of the situation in the countryside had failed before the outbreak of World War II. From the perspective of the village, an important role was played, however, by competitions on the cleanest rural farms, organized by the team of Dr. Kacprzak, which was, in fact, a form of practice of health education in the field.

Its promotion, just like preventive activities, was, however, very difficult in practice, and one of the main problems was the attitude of the then part of the medical community. As M. Kacprzak wrote:

The work related to general hygiene is looked at disdainfully by the doctors and, from the standpoint of professionalism, and from the point of view of results, and from the point of view of the methods used, which seem completely alien to an ordinary doctor [...] A doctor-practitioner does not like hygiene. The administrative tasks of a hygienist are totally alien to the doctor, but every doctor wants to see the patient, an individual, diagnosed specifically with a particular disease. In this way, the doctor's mind is trained during university studies; in this way the practice is established. Meanwhile, in the work of social hygiene it is necessary to completely reverse the mental attitude. One need to think more abstractly, the phenomena must be assessed on the basis of numbers, and the conclusions are to be derived from them. How to reconcile these two worldviews? ${ }^{40}$

The post-war generation of depleted medical staff repeatedly followed this pattern of thinking. As is apparent from the archival materials, at least until mid-1950s the prevention of diseases (including the infectious ones) was also very often underestimated by many doctors and medical personnel. ${ }^{41}$

${ }^{38}$ S. Kosiński, S. Tokarski, Ochrona zdrowia ludności wiejskiej (ze szczególnym uwzględnieniem Lubelszczyzny), Warszawa-Łódź, 1987, pp. 19-24.

39 Ibid.

${ }^{40}$ M. Kacprzak, op. cit., p. 94.

${ }^{41}$ This applied particularly to hepatitis but also to other diseases. 
The health education was also poor, the form and content not well addressing the (most often) uneducated population, using other categories of thinking. As emphasized by a former rural doctor, the simplest forms of health education, i.e. brochures, posters or talks in practice hardly fulfilled its functions:

People, not feeling the need to know the content of brochures, did not read them at all and used them as the wastepaper for which they obtained an right to buy some materials under allocation, or used them as a package. Others again took the brochure for accurate orientation in a disease, which would make it easy to get off work. ${ }^{42}$

The ineffectiveness of health education on paper was also discussed by one of the participants of the meeting at the Ministry of Health:

Our propaganda aiming at fighting infectious diseases in the country does not take the rational way [...] so far we relied on propaganda in the form of booklets and posters. The living word was in fact on the third set. What was the outcome? What did the voices from the area say? Well, a number of people are not quite ready to understand the diseases, and after reading the brochure they discover themselves ill. It was like that. Dozens of patients came to the doctor and troubled him to have them treated for venereal diseases and despite all the doctor's explanations - the patients did not believe in it. Each student in the fourth year of medical school is experiencing the same thing so what to speak of the peasants. ${ }^{43}$

Problems with popularization of knowledge related to health and hygiene were not only the consequence of forms of communication primarily there was lack of places and persons, directly responsible for this activity. Both in case of the rural areas and smaller urban centres, at least until 1954, the propagator's role was to be played by the local staff of the outpatient institutions. Typically, this issue was underestimated by them. Since 1952 there were field sanitary-epidemiological stations, but by the end of the 1950s in the most neglected (and therefore most in need) areas they struggled with huge staffing shortages. ${ }^{44}$

${ }^{42}$ Pamiętniki lekarzy (1968), p. 838.

${ }^{43}$ AAN, MZGW, ref. no. 55, Narady aktywu pracowników służby zdrowia w Ministerstwie i terenie, protokoły, stenogramy, korespondencje, 1953 r., Stenogram krajowej narady aktywu służby zdrowia z dnia 19 grudnia 1953 r., leaf 250 .

${ }^{44}$ AAN, MZ, GMWP, Posiedzenie Kolegium Ministerstwa 10-15. Protokoły, załączniki 1956, ref. no. 1/25, Ocena stanu zdrowia na wsi na podstawie analizy wykonania Uchwały Kolegium dot. wsi w latach 1954-1955, leaf 185. 
Also, the activities of the Red Cross agencies, supporting the health education, performed in the area, were unsatisfactory. ${ }^{45}$

It should, however, be emphasized that the problems of health education were also related to urban residents. Lack of hygiene habits, low health awareness and the slow rebuilding of the country from the ravages of war meant that also there the living conditions left much to be desired.

Problems with access to drinking water, big as they were almost everywhere in the country, intensified even more due to the expansion of housing developments. Back in the 1960s the problems with the water intakes, insufficient for the urban population growth, have been written about. Water shortages of course translated into hygienic conditions and the intensity of the spread of the dirty hands diseases. ${ }^{46}$

\section{The intensification of health education and the village hygienic programme}

Recognizing not only rural or provincial, but also the nationwide problem, the top-down actions have been undertaken to strengthen the work on improving sanitary conditions in the country.

In 1954 the State Sanitary Inspection was appointed - an institution responsible for conducting sanitary supervision and popularizing the rules of hygiene. The sanitary inspectors, working within its framework, were entitled to audit compliance with sanitation rules in urban neighbourhoods and rural communities.

They could also impose penalties in case of persons, both legal and natural, who failed to comply with the rules. ${ }^{47}$ Although the right to apply financial penalties was effective at times - forcing the rural households (both the state and cooperative) to implement the sanitation improvements, it was a very common problem to find people willing to execute the punishment:

The ordinal sanitary commission was here, but soon ceased its activity. Why? The replies were provided by the President of GRN, Paweł P. "It is a thankless job. We need to expose the peasants. Unsanitary conditions are almost everywhere. So everyone should be punished. If I was told to go to

${ }^{45}$ Ibid.

${ }^{46}$ More on the changes of sanitation conditions in Polish cities after 1945 in my article: "Warunki sanitarne w powojennej Polsce. Zarys problemów i dynamiki zmian (1945-1970)", Polska 1944/45-1989. Studia i Materiaty, 11, 2014, pp. 277-299.

${ }^{47}$ Dz.U., 1954, no. 37, item 160. 
the people and make them aware that the dunghill is too close to the well, or a lavatory maintained in an unhygienic manner, I would have resigned from the office immediately". ${ }^{48}$

In the province of Cracow (believed to be one of the better ones in terms of the village sanitary conditions) it was emphasized that the lack of local sanitary inspectors was so large that it was necessary to hire commuters from surrounding towns for this position. ${ }^{49}$

However, sometimes the financial penalties imposed for failing to comply with the centrally issued recommendations were accepted by the directorates of rural establishments (mainly PGR, POM) more willingly than carrying out the work to improve sanitation conditions. Moreover, the same was true still in the 1970s in relation to many city factories (especially those related to food, catering, etc.).

The bottom-ups support for the work of health inspectors was to be provided by the local and rural community organizations, such as the Rural Youth Union (ZMW), field Red Cross agencies or the Housewives' Country Club (Koło Gospodyń Wiejskich). Their members were recruited mainly from the rural population of the younger generation, to which the hygiene concepts spoke with greater efficiency. Also, experimental action of village hygienization was launched, initially only in the selected areas of Poland. Soon, it was extended to the whole country, and was slowly bringing its first results.

Within ZMW the so-called rural health schools were organized, which boiled down to a cycle of talks on personal hygiene and environmental health. They were generally conducted by doctors, nurses or midwives. The so-called schools for mothers were also organized, which were a kind of courses for pregnant women and young mothers. These courses consisted of a few or several lectures and practical classes.

The efforts to improve the health knowledge in the country included also the training of the so-called health forewomen (as part of the Red Cross). In addition to providing the residents with first aid, they were taught how to deal with the sick at home and how to nurture babies. They also took part in the organization of cleanness competitions and educational competitions, as well as health and educational campaigns such as competitions for the cleanest village, or the "Days of tuberculosis", "Health Week", "Oral Health Week", "Spring Cleaning Action”, etc. ${ }^{50}$

${ }^{48}$ Gromada Rolnik Polski, 1958, no. 31, p. 7.

${ }^{49}$ ANK, WSSE, ref. no. 168.

50 AAN, Central Committee of the Polish United Workers' Party (hereafter: KC PZPR), ref. no. 237/XIV-212, Protokół z posiedzenia Komisji Socjalnej, odbytego w dniu 
The scale of the activities carried out annually varied and largely depended on the development of health services in the area. Overall, however, as the report for 1962 states, the number of activities in the country, in terms of the numbers looked pretty miserable: talks were delivered 48,798 times, 5,045 various cleanness competitions were organized, and 23,417 sanitary controls were performed. 5,352 films about educational and sanitary themes were presented, 18,950 posters were printed and more than 2,700 health forewomen were trained. In addition, 161 contests for the cleanest village were organized, attended by 240 villages $-5,168$ farms. As part of the aforementioned actions, 749 wells, 365 buildings, 255 lavatories and 919 dunghills were built or renovated, 624 roofs got fixed, 766 barns were whitewashed, 90 places to wash dishes were founded and 76 vegetable and flower gardens were organized. ${ }^{51}$

They were, therefore, drops in the ocean of needs. But what is important, the representatives of local authorities very often could jeopardize this modest effort with their attitude: they either did not have or did not solicit the funds for the regular continuation of the initiated sanitary work or they ignored in their decisions the health and hygiene issues.

So, in spite of the propaganda and the official course of the social and health policy, local rural activists still faced many difficulties. Although the attitude of the inhabitants of the villages changed, and they were increasingly demanding the authorities to organize a health centre close to their village, or to at least provide a convenient way or means of transportation to the functioning facility, the representatives of local authorities (municipal or national council of the community) required much more time (at least until the end of the 1960s) to change their approach. A major obstacle was the lack of a deeper care and regular cooperation on the part of the regional Red Cross agencies and the nearest health centre. ${ }^{52}$ In such a situation, it is not surprising that, as estimated, in practice only half of the above-referenced health forewomen actually were able to work in the field.

30 VI 1963 r. poświęconego podniesieniu stanu oświaty sanitarnej w kraju. Analiza sytuacji w oświacie sanitarnej w Polsce, leaf 148.

${ }^{51}$ Ibid., leaf 150. It is worth noting that in 1960 there were 6331 communes in Poland. Each commune consisted of a few to several rural communities. In one village there were sometimes even hundreds of farms.

${ }^{52}$ AAN, KC PZPR, ref. no. 237/XIV-212, Protokół z posiedzenia Komisji Socjalnej, leaf 160 . 


\section{But changes did happen}

Although up till now I have not been able to determine how the above-described sanitation actions and educational approach in fact changed the attitudes of the rural population in relation to health and safety issues, i.e. statistics provides information on the transformations, gradually taking place in the 1960s and 1970s. The mandatory schedules of vaccinations, introduced in the 1950s, supplanted most dangerous infectious diseases (smallpox, polio, typhoid and dysentery). Since the mid-1960s a small number of new cases of tuberculosis were also reported. Although some of the "diseases of dirty hands" (including hepatitis/viral hepatitis), parasitic diseases (helictotrichon, lice, etc.), food poisoning and injuries of the body were still major problems, it is worth remembering that the problem affected the entire Polish population.

In the countryside, there was still a high frequency of zoonoses, as well as respiratory and musculoskeletal system diseases (discussed in terms of agricultural occupational diseases). In the entire Polish society, and also in the rural areas the incidence of lifestyle diseases (cardiac, cardiovascular, cancer, psychiatric illness) also increased in this time ${ }^{53}$.

However, there was a clear decline in the infant mortality rate in the countryside (in 1950116 deaths per thousand live births were reported, and in 1970 it was $34.8^{54}$ ), which is a widely accepted barometer of the state of health. Although the decline in child mortality was associated mainly with the increasing number of hospitalized births and vaccinations, the improvement of living conditions, more noticeable in the late 1960s and 1970s, was also of great importance. One of the most important measures was the interior equipment of the flats. In 1960 the number of households equipped with a water system (water supply) was 3.7 per cent, and in 1970 it increased to 12.1 per cent ${ }^{55}$. During this time, the water quality has also significantly improved.

The construction boom, associated with favourable loans for the villages in the second half of the 1950s and the 1960s also gradually changed the sanitation image of the Polish village. New construction, in connection with a number of obligations imposed, usually took into account the sanitary standards (size of the windows, ventilation,

53 S. Klonowicz, "Stan zdrowia ludności Polski w latach 1950-1973. Próba oceny na podstawie wybranych informacji statystycznych", Studia Demograficzne, 1975, no. 40, p. 147.

${ }_{54}$ Maty rocznik statystyczny 1974, Warszawa, 1975, p. 29.

${ }_{55}$ Ibid., p. 225; Rocznik statystyczny gospodarki mieszkaniowej $i$ komunalnej 1965, Warszawa, 1967, pp. 28-29. 
distance from farm buildings, basement and etc.). The rural electrification, realized in 90 per cent in 1960, was also of great importance. ${ }^{56}$ It primarily changed the attitude of peasants towards the conditions of the area surrounding their houses. However, as marked by one of the rural inhabitants, the improvement of the living conditions most frequently went hand in hand with the fact that the family, next to the income from the farm, also had additional income, obtained by one of the members of the family in a nearby factory or a state enterprise. It was these so-called farmer-worker's farms, forming in the late 1960s and 1970s up to half of all farms in some areas, which, without a doubt, shaped new habits and customs in the countryside. Farmers-workers, and also farmers-officials (employed in offices and administration), as richer, more mobile and with a more "familiarity", usually were also the first in the village to buy new equipment (motorcycles, cars, but also household appliances), aspiring to the urban lifestyle. It was them, too, who, using the city or factory bath, often understood the need to have a home bathroom and usually were faster to install the fixtures in their own homes. Of course, the items they purchased and hygienic attitudes exhibited met with a mixed response of the remaining part of the rural community. One of my interlocutors told an interesting story about this phenomenon: "[Husband] came to the house and said: [...] 'Will I be the worst here? Because half the municipality establishes the water intake' [...] and only then did we do it". ${ }^{57}$

The aspect of "not being worse than the rest" in a small, not anonymous, rural community was very important. However, I find it difficult at this stage of the study to say how much the declared habits, equipment purchased and renovated buildings actually translated into the improvement of personal hygiene of the rural population. Undoubtedly, however, the important role was played by the health education described above, as well as the knowledge acquired in schools, boarding schools and during non-agricultural work. Control tests in collective institutions must have also had an impact. Another factor which played an important role was the then media, with a clear positive attitude towards the value of the cleanliness of the body and of the environment.

First, the walking cinemas, and then radios and TVs, acquired commonly in the countryside, facilitated the transmission of the propagated images. Rural youth, aspiring to live in the city, was motivated to change

${ }^{56}$ M. Gorczyca, Regionalne zróżnicowanie warunków mieszkaniowych $w$ Polsce w latach 1950-1988, Warszawa, 1992, p. 86.

${ }^{57}$ P.G., place Ż, Lublin Voivodeship, 2008. 
hygiene habits by a well-known stereotype functioning of the urban population of the dirty and stinking peasants. ${ }^{58}$ Dressing and combing according to the current trends, spending time according to the urban style and the acquisition of many other habits (including hygiene) - all this has often facilitated feathering in the urban crowd and avoiding the stigma, a heavy burden, connected with the social origin.

\section{Conclusions}

The view of a modernised and a civilised renewed countryside, that would separate from its "regressive" and "superstitious" past by means of its progressiveness, idealised in the 1950s, had little in common with reality, and was nothing but a propaganda project. The project's purpose was to legitimise the construction of a new system, in which the idea of a progressive welfare state was to play a major role.

In reality, the 1950s, in regard to hygiene and health awareness, were quite diverse. Despite the dominating poverty and infectious diseases took a significant toll on the population of cities, as well as, of the countryside, the emerging (particularly in major and generally more prosperous cities) health centres and labour wards would increasingly affect the approach of the residents of the countryside to health issues and, in consequence, to their daily habits. The most significant change was brought only within the first decade to the so-called Polish October (or Polish Thaw). Additionally, it was a time when the general health and sanitary policy was subject to transition. It was then, that the Polish Centre for Disease Control and Prevention (Państwowa Inspekcja Sanitarna) was introduced, along with a number of regulations controlling the principles of landscape planning. A mandatory vaccination schedule was presented at the time, soon followed by the program of countryside hygienisation. At the end of the 1950s, complimentary sanatorium treatment was provided to countryside residents with tuberculosis. The turn of the 1950 s and the 1960 s was also a time of an increasing migration

${ }_{58}$ To illustrate the phenomenon it is worth quoting one of the situations described in the 1960s: "One time in the 'Sibilla' cinema there was the performance of a band, I do not remember which one, and in the room there was a woman from a village in the shoes, the so-called. jackboots. She sat on the bench there was plenty of room next to her. People from Puławy came, and one of the ladies said to the woman from the village: 'You lady move, came from the village and her shoes stink with dung"', quoted after: Pamiętniki z rejonu płockiego i puławskiego, selection and prep. by E. Jagiełło-Łysiowa, F. Jakubczak, Warszawa, 1967, p. 331. 
of countryside residents to cities, and of the increasing number of the group regarded to as "chłoporobotnicy" (farmer and worker group). The cultural and social gap, narrowing due to countryside mobility and compulsory education allowed for the appearance and perpetuation of new ways of thinking and of new daily practices. However, the aforementioned did not result in a simply obedient adoption of top-down rules of everyday practices - numerous habits (as daily oral hygiene, diet habits and the principles of infant care) required a longer amount of time and was in a way "negotiated" by countryside residents with the healthcare representatives operating in the region.

\section{Bibliography}

Florek-Łuszczyk M., Higienizacja polskiej wsi jako ruch socjomedyczny, Lublin, 2015.

Fogt B., "Poznański Ośrodek Reumatologiczny w kontekście zmian zachodzących w ochronie zdrowia w latach 1952-2005", PhD dissertation under Prof. Dr. hab. M. Musielak, source: Wielkopolska Biblioteka Cyfrowa, http://www.wbc.poznan.pl/Content/249324/index.pdf (accessed: 19 Dec. 2014).

Gorczyca M, Regionalne zróżnicowanie warunków mieszkaniowych w Polsce $w$ latach 1950-1988, Warszawa, 1992.

Jarosz D., Obraz chłopa w krajowej publicystyce czasopiśmienniczej 19441959, Warszawa, 1994.

Jarosz M., Kosiński S., "Geneza i zmiany strukturalne wiejskiej służby zdrowia", in: Stare i nowe struktury społeczne $w$ Polsce, vol. 2: Wies, ed. by J. Styka, Lublin, 1995.

Kacprzak M., Konkursy „Zdrowie w chacie wiejskiej”. Sprawozdanie i uwagi krytyczne, Warszawa, 1930.

Klonowicz S., "Stan zdrowia ludności Polski w latach 1950-1973. Próba oceny na podstawie wybranych informacji statystycznych", Studia Demograficzne, 40, 1975, pp. 131-148.

Kosiński S., Tokarski, S., Ochrona zdrowia ludności wiejskiej (ze szczególnym uwzględnieniem Lubelszczyzny), Warszawa-Łódź, 1987.

Ksiega pamiatkowa Zjazdu Medycyny Wiejskiej w Lublinie: $z$ okazji X-lecia Instytutu Medycyny Pracy i Higieny Wsi im. Witolda Chodźki 1951-1961, ed. by J. Parnas, Lublin, 1964.

Maty rocznik statystyczny 1974, Warszawa, 1975.

Miernik G., "O niektórych patologiach życia codziennego mieszkańców obszarów przyczółkowych w drugiej poł. lat 40. XX w. (na przykładzie woj. kieleckiego)", in: Bieda w Polsce, ed. by G. Miernik, Kielce, 2012, pp. 195-216.

Nowe zawody: pamiętniki, prep. and introduction by B. Gołębiowski, Z. Grzelak, Warszawa, 1969. 
Organizacja ochrony zdrowia, ed. by J. Indulski, Warszawa, 1984.

Pamiętniki lekarzy, ed. by J. Borkowski, Łódź, 2011.

Pamiętniki lekarzy, ed. by K. Bidakowski, T. Wójcik, Warszawa, 1968.

Pamiętniki z rejonu płockiego i puławskiego, selection and prep. by E. Jagiełło-Łysiowa, F. Jakubczak, Warszawa, 1967.

Piątkowski W., Lecznictwo niemedyczne w Polsce. Tradycja i wspótczesność, Lublin, 2008.

Rocznik statystyczny gospodarki mieszkaniowej i komunalnej 1965, Warszawa, 1967.

Stan zdrowotny i higiena wsi lubelskiej. Materiaty z obozów naukowo-spotecznych 1954-1960, ed. by S. Grzycki, A. Tuszkiewicz, W. Szewczykowski, B. Wawrzyszuk, Lublin, 1964.

Szpak E., "Warunki sanitarne w powojennej Polsce. Zarys problemów i dynamiki zmian (1945-1970)", Polska 1944/45-1989. Studia i Materiaty, 11, 2014, pp. 277-299.

Wawrzyszuk B., "Stan sanitarno-higieniczny wsi", in: Oświata sanitarna na wsi. Higienizacja wsi, Warszawa, 1962.

Wieś polska 1939-1948. Materiaty konkursowe, vol. 2, prep. by K. Kersten, T. Szarota, Warszawa, 1968.

Ewelina Szpak

Personal hygiene and public health care in the Polish countryside after 1945 - propaganda against reality

(Summary)

Immediately after World War II, the state of health of people living in rural areas resulted from, on the one hand, civilisation backwardness and, on the other, from poverty and a specific spatial isolation of the Polish countryside. From the mid-1950s, health awareness of the rural population based on traditional outlook was under increasing pressure of the state. The health and hygiene policy of the Polish People's Republic in relation to rural areas was inconsistent in many respects. Exclusion of a large part of rural population from the system of free healthcare petrified their anxieties and distrust of the state medical assistance. Aggressive collectivisation in the first half of the 1950s added to the peasants' distrust of state institutions entering the countryside.

Often, grass-root activities of many physicians and paramedics to improve peasant hygiene and state of health played a specially important role, triggering the process of grass-root changes in the sphere of rural attitude towards health. Due to organizational, infrastructural, and staff limitations, however, their importance was often of local character and was spread over time.

A significant change took place in the 1960s, when the succession of generations increased the opening of the countryside for external culture that also 
yielded to new social patterns penetrating rural culture through the increased external mobility, universal access to education and media culture (radio, television, cinema).

Ewelina Szpak - dr nauk humanistycznych (Uniwersytet Jagielloński, 2010), od 2012 r. pracuje w Instytucie Historii im. T. Manteuffla Polskiej Akademii Nauk. Specjalizuje się w badaniach historii społecznej i kulturowej PRL, historii mentalności oraz społecznej historii medycyny i historii środowiskowej.

Ewelina Szpak - PhD in humanities (Jagiellonian University, 2010), since 2012 employed at the Tadeusz Manteuffel Institute of History of the Polish Academy of Sciences. She specialises in the social and cultural history of the Polish People's Republic, history of mentality, social history of medicine and environmental history.

E-mail: enka2@o2.pl. 